\title{
Social Aspects of State Regulation of Agricultural Production
}

\author{
Lesia Barabash $^{1 *}$, Mykhailo Malovanyi ${ }^{1}$, and Alla Osipova ${ }^{1}$ \\ ${ }^{1}$ Uman National University of Horticulture, 20305 Uman, Ukraine
}

\begin{abstract}
State regulation of agricultural production in Ukraine is aimed at increasing production and ensuring food security of the country and its population. However, the low level of social development, as well as social problems, which in rural areas among the population have now become particularly acute, reduce the potential of this area of the national economy. That is why the question arises of finding active incentives, tools and mechanisms that would encourage the rural population to act and create a promising basis for improving its social status. One of the main existing problems of state regulation of agricultural production in Ukraine is the provision of financial incentives to large agricultural producers. And although such a policy has allowed to increase export potential, but has led to the destruction of rural areas and the impoverishment of the rural population. The intensive activities of these producers on the basis of intensive technologies have led to significant imbalances in the development of the industry with the prevalence of crop production and the decline of livestock, reduced soil quality, as well as rising unemployment of the rural population. This has led to an increase in the shadow sector through illegal activities and hidden income.
\end{abstract}

\section{Introduction}

State regulation is one of the mechanisms of influence of the administrative apparatus on the development of the economic environment of the country. And depending on which industry or sphere of activity will become a priority of state regulation, such will be the vectors of development of the entire national economy.

Ukraine is a country with a strong agricultural potential. Therefore, it is quite obvious that agricultural production should be a priority for the interests of the state in general and state regulation in particular.

Currently, among the priorities of state regulation of Ukraine, implemented through reforms in the country, are sustainable long-term economic, social and environmental development, as well as innovation, institutional and comprehensive growth [1]. These goals, indeed, are general, because they do not contain relevant specifics and cover all possible aspects of state activity. However, we consider it necessary to focus exclusively on the social components of state regulation in a particular area - agricultural production.

During the long 30-year period of functioning of state regulation of agricultural production in Ukraine, social aspects were leveled, which provoked the decline of rural areas and the outflow of productive citizens. The lack of adequate social infrastructure, adequate social protection and development prospects only exacerbates the crisis.

\subsection{Problem Statement}

The issue of strengthening the social direction of state regulation in the field of agricultural production in order to strengthen its development is currently one of the most relevant, especially in the post-pandemic period, when the entire economy has suffered significant losses. That is why the object of the study is the peculiarities of state regulation of the development of agricultural production in Ukraine in the social context.

The subject of the study was the financial and economic relations that arise at the intersection of the interaction of the state and agricultural producers in order to improve the social situation of the rural population in particular and rural areas in general.

\subsection{Related Work}

The problem of state regulation of the development of agricultural production in order to improve the social development of rural areas is not unique to Ukraine. It faces all nations of the world and its main goal should be to eradicate poverty by achieving an adequate level of food supply in case of population growth.

«Achieving food security cannot be accomplished without ending poverty in developing nations», said Frances Bekele and Isaac Bekele, [2] while noting the innovative change in agricultural production technologies and approaches to state social policy to reduce rural poverty.

Randy Stringer \& Prabhu Pingali also emphasizes the need to develop agricultural production in line with innovation [3]. The authors note that a balanced state policy to regulate agricultural activities can help attract additional investment in this sector of the national economy, which will encourage increased production, improve food security, reduce poverty and 
unemployment, as well as optimize the social and environmental situation as in rural areas in particular and in the state as a whole.

Y. Kustepeli, Y. Gulcan, M. Yercan, et al. focus on the possibilities of activating the social component in rural areas and the cooperative component of agricultural production [4]. As a result of the surveys, the authors have found that agricultural cooperation can significantly affect the growth of the social component and income of the rural population.

I. Zastozhnikova emphasizes the need to intensify the social priorities of state regulation in the agricultural sector: «... the task of regulating agriculture... should be derived... from the objective provisions of development and focus on the criteria of economic and social efficiency» [5].

O. Khodakivska and O. Mohylnyi emphasize the significant negative consequences of the current state regulation in Ukraine with the support of agricultural holdings [6].

In general, it should be noted that modern financial and economic systems, in this period of pandemic crisis and expected post-pandemic economic downturns, are actively striving to strengthen the social component. And as soon as possible this trend should be implemented in agricultural production as a basic component of food security.

\section{Research results}

\subsection{Current state of state regulation of agricultural production in Ukraine}

Since 1990 and until now, state regulation of agricultural production in Ukraine has pursued the goal of creating a strong market for agricultural products. Among the areas of implementation of these goals - direct budget subsidies to reimburse agricultural producers for parts of the costs and to support the development of industries, as well as state target development programs for individual programs. The instruments used to achieve these goals include budget financing, price support, mechanisms for preferential lending and taxation, risk insurance and financial support for leasing procedures. However, the volume of financial support for agricultural producers was quite low, as in most post- Soviet countries (Fig. 1).

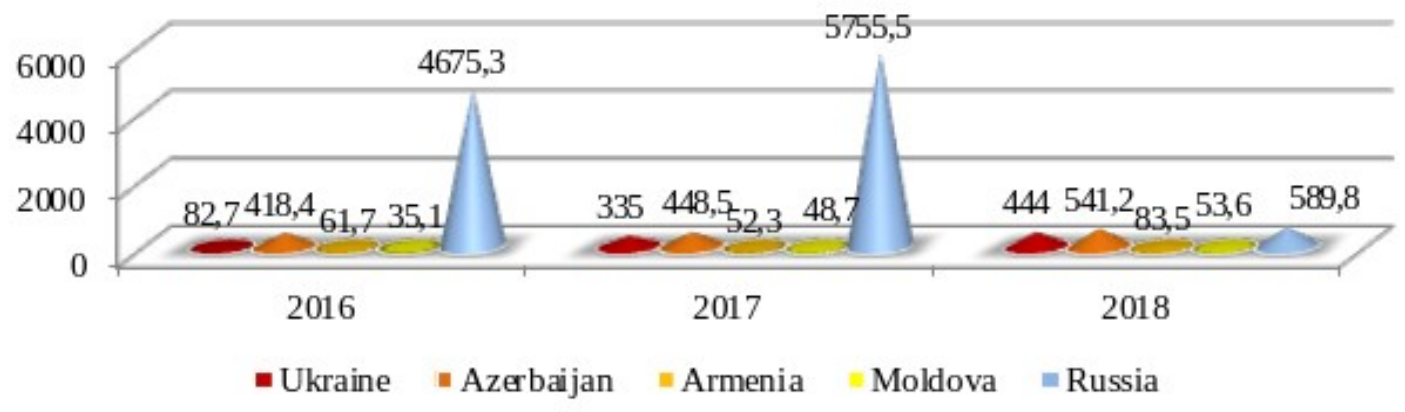

Fig. 1. Volumes of budget financing of agricultural production in some countries of the post-Soviet space [7]

At the same time, the methodological basis of state incentive processes is the legislative protection of property rights and information and legal services for agricultural producers, as well as the implementation of the coercion system under antitrust law, standardization and certification of products and more.

However, there is a significant drawback to all of the above: access to the proposed programs and subsidies is enjoyed mainly by large, in some cases medium- sized farmers, while small ones remain outside the incentive field. The actual consequences of these actions were the impoverishment of rural areas, reduced welfare of the rural population, as well as soil degradation and imbalances in the development of the agricultural sector.

In general, the goal of increasing sales of agricultural products abroad and increasing export potential was achieved (Fig. 2). 


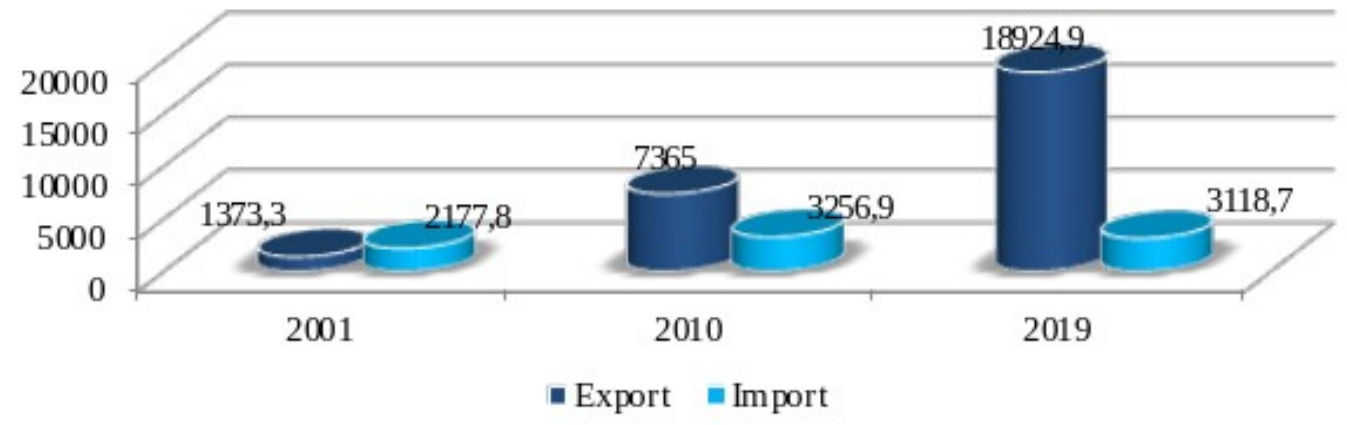

Fig. 2. Dynamics of volumes of export and import of agricultural products of Ukraine, million dollars USA [8]

Despite the general positive, the overall growth in agricultural exports was achieved through growth in crop production. After all, since 1991, the increase in sown areas of cereals and legumes amounted to 647 thousand hectares, sunflower - 4327 thousand hectares. At the same time, the sown areas of sugar beets (-1336 thousand ha) and potatoes (-224 thousand ha), vegetables (-25 thousand ha), fruit and berry crops (617 thousand ha) decreased significantly.

Livestock sales remained low: during the same period the number of livestock and poultry also decreased: cattle - by 21.9 million heads, pigs - by 13.9 million heads, sheep and goats - by 7.7 million heads, poultry - by 43.4 thousand heads.

In addition to the fact that the export potential of the state is not realized in full force, negative changes are observed in the food security of the state, which provokes an imbalance in the diet of the population (Table 1).

Table 1. Consumption of food by households in Ukraine, kg on average per month per person [9]

\begin{tabular}{|l|c|c|c|c|c|}
\hline Type of food & $\mathbf{2 0 0 1}$ & $\mathbf{2 0 1 0}$ & $\mathbf{2 0 1 8}$ & Minimum consumption rate & Rational consumption rate \\
\hline Meat and meat products & 2,8 & 5,1 & 4,9 & 4,3 & 6,7 \\
\hline Milk and dairy products & 17,3 & 19,2 & 19,1 & 28,4 & 31,7 \\
\hline Eggs, pcs & 16,0 & 20,0 & 19,0 & 19,0 & 24,0 \\
\hline Fish and fish products & 1,4 & 1,8 & 1,4 & 1,0 & 1,7 \\
\hline Sugar & 3,3 & 3,0 & 2,7 & 2,7 & 3,2 \\
\hline Oil and other vegetable fats & 2,0 & 1,8 & 1,5 & 0,7 & 1,1 \\
\hline Potato & 11,1 & 7,7 & 6,3 & 8,0 & 10,3 \\
\hline Vegetables and melons & 9,0 & 9,5 & 8,9 & 8,8 & 7,4 \\
\hline Fruits, berries, nuts and grapes & 2,2 & 3,7 & 3,8 & 5,7 & 8,4 \\
\hline Bread and bakery products & 10,7 & 9,3 & 8,3 & 7,8 & \\
\hline
\end{tabular}

That is, we have a clear idea of the need to increase

Based on the previous data, we see that during the study period, the population of Ukraine feels the need for almost all of these foods. The volumes of consumption of production and processing of plant products are approaching rational norms: bread and bakery products and sugar, exceed the rational norms of consumption of oil and other vegetable fats. At the same time, there is a significant shortage of products of animal origin - meat and meat products, dairy products, eggs. production of livestock products in particular and quality agricultural products in general.

One of the striking results of the state's disincentive influence on the social aspects of Ukraine's agricultural production is a reduction in the number of jobs and livestock, and thus an increase in unemployment in rural areas (Fig. 3). 


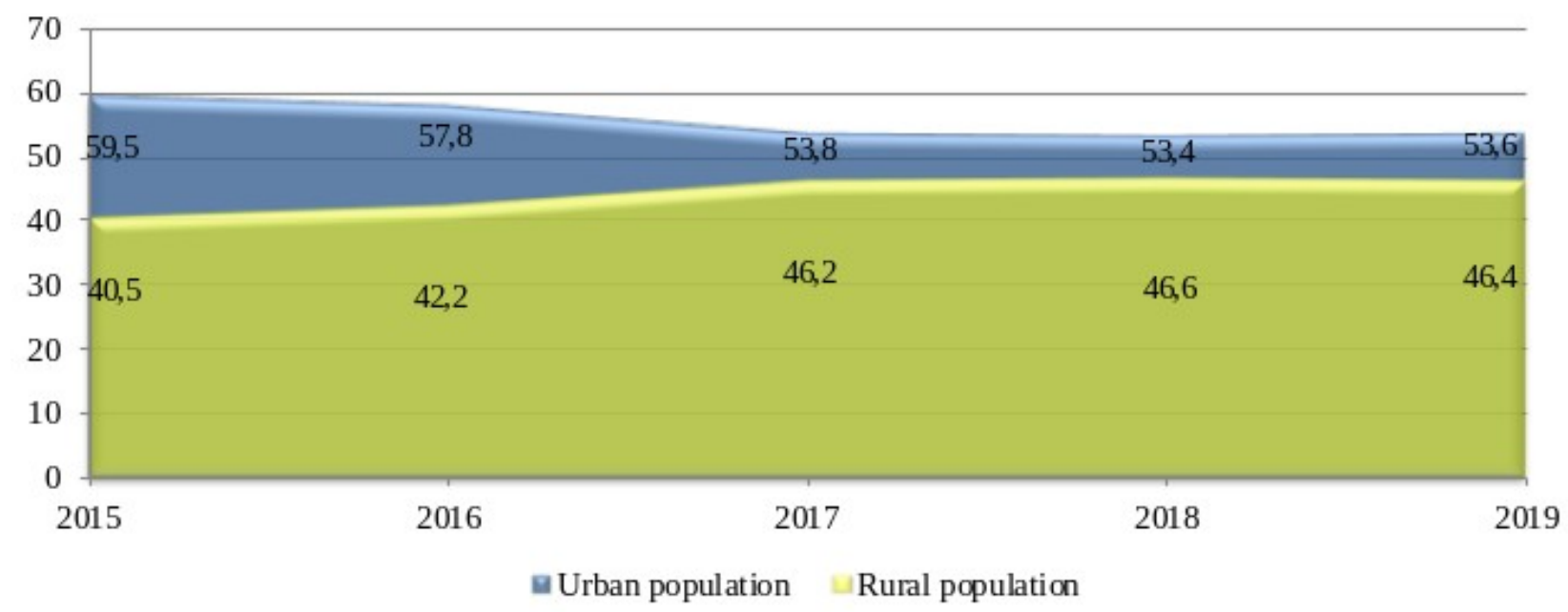

Fig. 3. The share of the unemployed population at the place of residence in the total number of unemployed in 2014-2018, \% [10]

Also, in addition to all the above, during the entire period of measures to stimulate the development of agricultural production, funds were never provided to improve the social component of this sector of the economy. As a result there was an increase in hidden employment (about 39\%), a high level of consumer price index for agricultural products, a decrease in investment activity in the agricultural sector and more.

\subsection{Directions for strengthening social trends in agricultural production in Ukraine}

Based on the current situation and existing foreign experience, we believe that the basis for the development of agricultural production in Ukraine in the near future, as well as the main vector of social policy in rural areas should be to stimulate small forms of agricultural production, which are now personal farms.

The reason for this statement is that rural households independently sell their products, and the demand for such products, which are organic, is constantly growing. As a result, the hidden employment and illegal income is appearing which is not covered in the statistics.

In general, over the past five years, there has been an increase in the number of small and micro enterprises in the agricultural sector (Fig. 4).

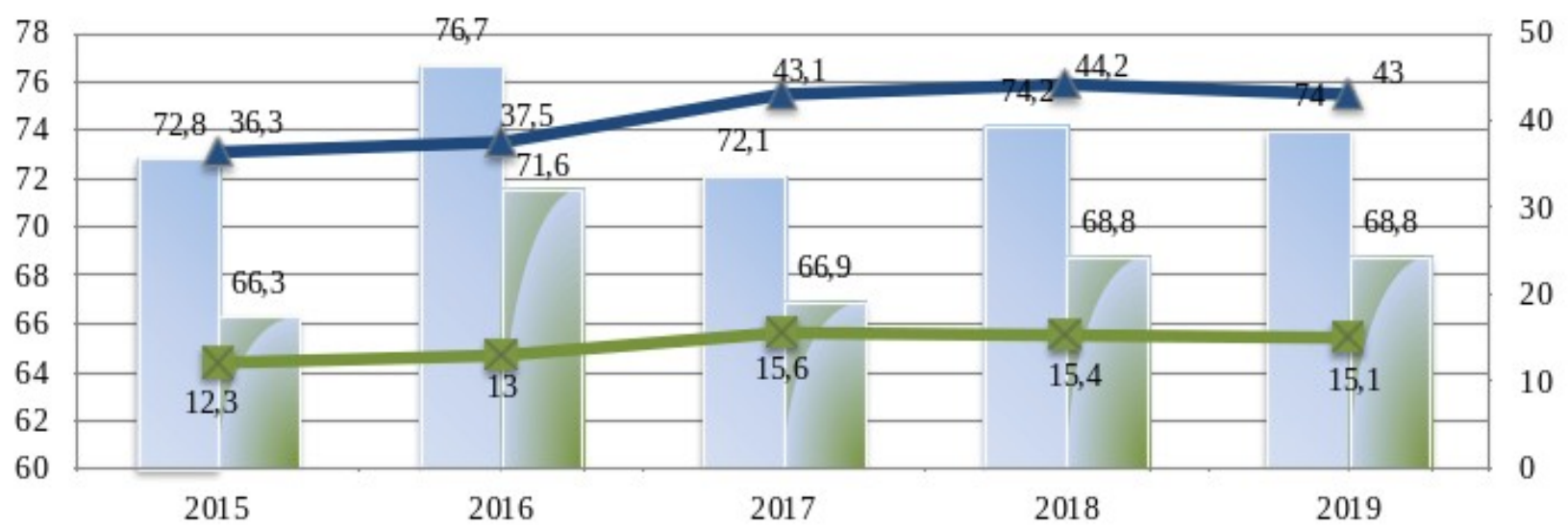

Small businesses

Miqroenterprises

The share of products sold by small agricultural enterprises in the total volume of sold agricultural products, \%

$-\mathrm{x}$ The share of products sold by midroenterprises in agriculture in the total volume of sold agricultural products, $\%$

Fig. 4. Dynamics of the number of small and microenterprises in the field of agricultural production of Ukraine in 2015-2019, thousand units [11] 
In accordance with the data of fig. 4, we can state a fairly high volume of agricultural products sold by small and microenterprises, in the total scale of agricultural products sold in the industry $-40.8 \%$ and $14.3 \%$ on average for the study period.

It should also be noted that the role of personal farms in agricultural production is very important (Fig. 5).

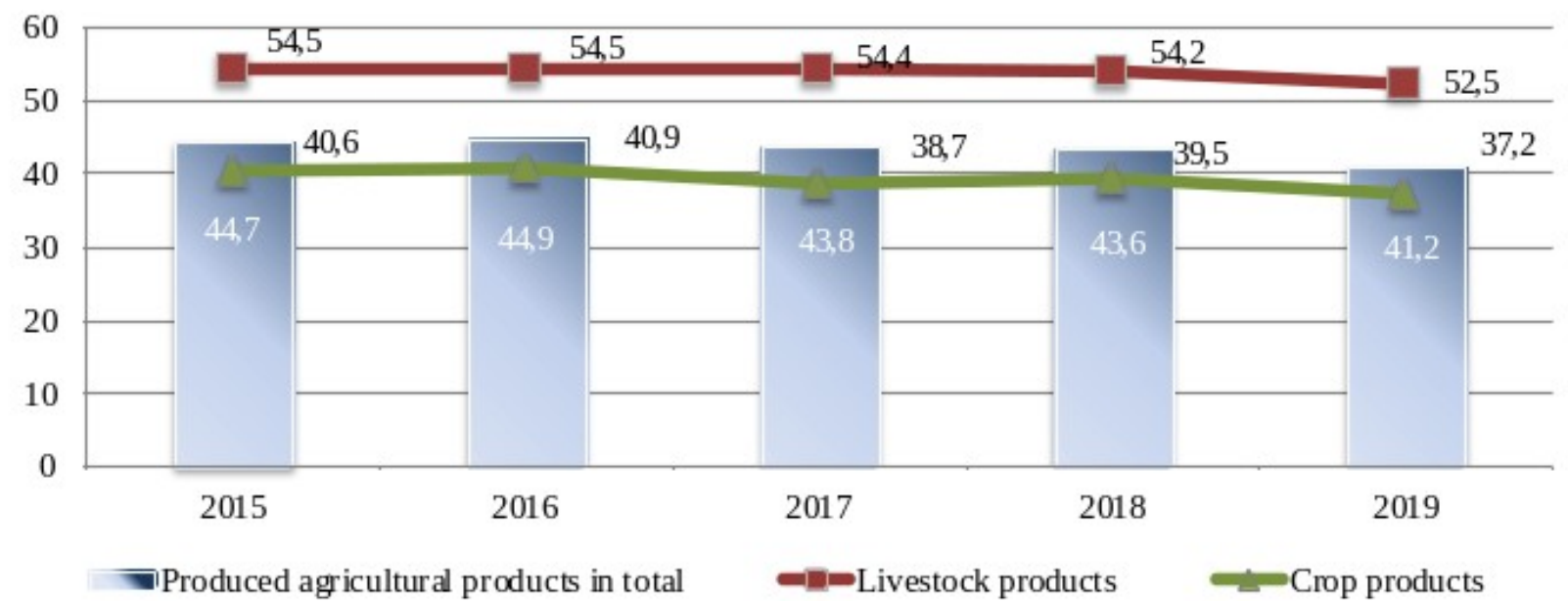

Fig. 5. Production of agricultural products by households (personal farms) (share in total agricultural production of Ukraine) in 2015-2019, \% [8]

Shown in Fig. 5 data prove that personal farms are potentially promising participants in the process of effective stimulation of agricultural production in Ukraine at the present stage. In addition, their inclusion in the range of objects of state regulation will be the first step towards the formation of a social policy for the development of rural areas of a new type.

In our opinion, the necessary reform of social policy in rural areas in the framework of state regulation of agricultural production should be carried out by encouraging small farmers to unite in territorial production clusters in order to implement productive agricultural activities. At the same time, such tendencies will correspond to the conditions of the decentralization reform, which envisages granting greater independence, primarily financial, to territories and local self-government bodies.

Thus, personal peasant farms, within the administrative-territorial unit, should unite according to the profile of the activity and carry out production activities in the profile associations - territorial production clusters. In 2019, there were 735 operating agricultural service cooperatives in Ukraine; the number of dairy cooperatives was fixed at 230 units.
There are separate cooperatives for tillage and harvesting, fruits and vegetables, grains, meat, and other services. However, their significant disadvantage is that they bring together farms from different regions, while increasing the cost of production at least at the expense of transport costs, as well as the lack of a closed production cycle. [12].

Given the peculiarities of agricultural activities, we believe that the territorial production cluster should unite the following participants: personal farms by activity (crop, livestock, harvesting, fish farming, etc.), processing plants, storage facilities, higher education institutions and research institutions.

Carrying out agricultural activities with the help of territorial production clusters will increase the production of environmentally friendly organic products, create stable markets, reduce logistics costs (and hence the price of finished products), introduce virtually waste-free production, and most importantly ensure basic social goals and increasing the level of employment in rural areas and the level of welfare of the rural population. Therefore, the model of the territorial production cluster, in our opinion, will look like this (Fig. 6). 


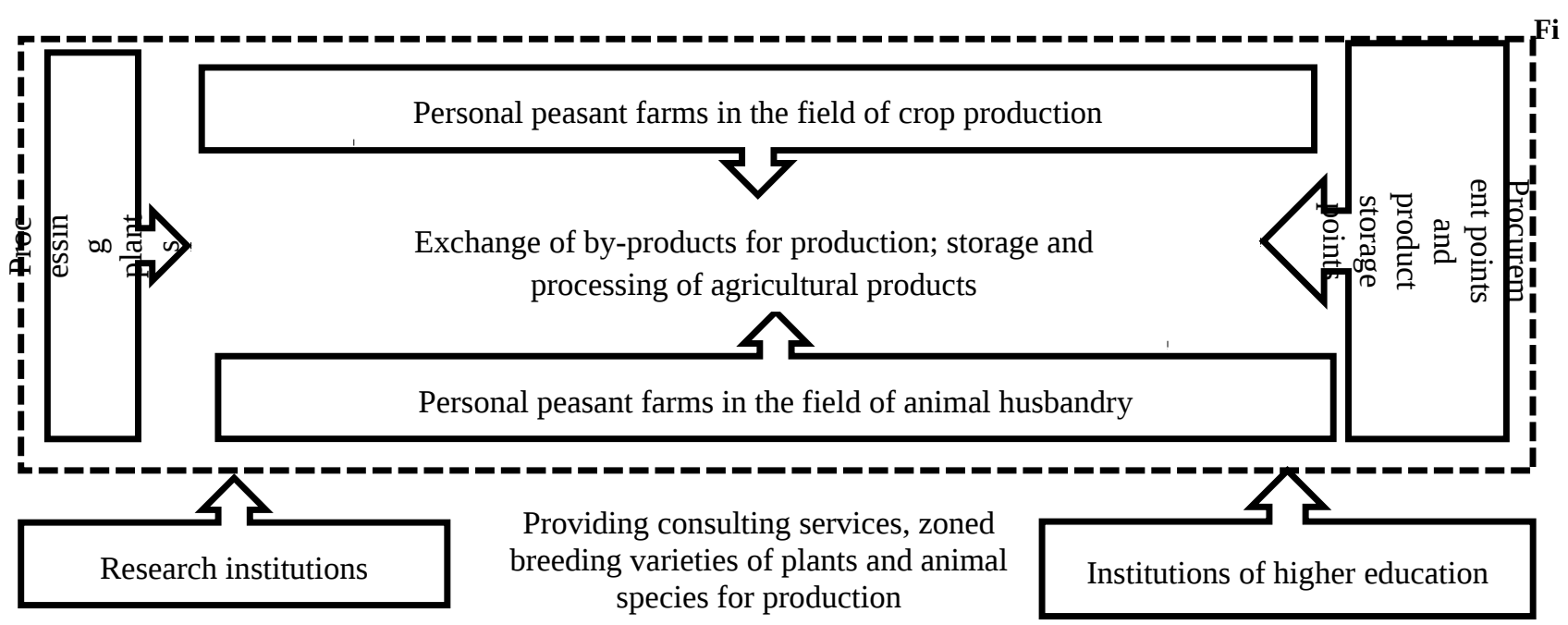

g. 6. Model of formation and functioning of territorial production cluster

In order to encourage peasant farms to join such an association, the state, for its part, will provide incentives in the form of cheaper loans, special insurance products and preferential taxation of certain businesses, especially those working in agricultural production, which are not popular in potential manufacturers through a long production cycle. Local authorities, in turn, must create a favorable social and logistical infrastructure, a positive tax microclimate (in terms of local tax benefits), to search for markets.

The peculiarity of the proposed model is that the production cluster includes research institutions and institutions of higher education, which provide small agricultural producers with raw materials for activities: biological assets, zoned breeding varieties of crops, animal species and more.

Microinsurance should become a promising element of stimulating small agricultural producers to production activities within territorial production clusters. Practiced in foreign countries exclusively for the category of low-income people, in this case it should involve small farmers in the financial market of the state. Therefore, to stimulate agricultural production, microinsurance should be carried out under the following conditions (Fig. 7).

Incentives for small farmers through microinsurance will help reduce the level of risks, both industrial and personal. To create a proper basis and form a field of social and financial protection, the state will act as a guarantor of insurance payments in the event of insurance events and will cover the costs of producers on insurance premiums for property and production insurance (natural risks, fires, theft, etc.).
Manufacturers will conclude personal insurance contracts (life, health, accident) at their own expense. Insurance rates for this type of insurance for this group of policyholders will be regulated by the state in agreement with insurance companies.

\section{Conclusions}

The analysis of indicators of state regulation of agricultural production in Ukraine showed an underestimation of the potential of small and micro production in this area. In particular, at the end of the study period there was an increase in the number of micro-enterprises in rural areas - by 2.5 thousand units, as well as the share of agricultural products sold by them of their own production in total agricultural production - by $2.8 \%$. At the same time, a negative indicator is the $5.9 \%$ increase in the number of unemployed in rural areas, as well as the low level of consumption by the population of Ukraine of necessary products produced in agriculture.

Based on the existing prerogatives and problems, as well as in light of the growing urgency of social issues in state regulation of agricultural production, we consider it appropriate to intensify financial and organizational components as necessary components for the formation of a proper social microclimate in rural areas. In particular, the creation of regional clusters will encourage small and micro-producers to be active, and micro-insurance will provide an opportunity to minimize the potential risks of production activities. 


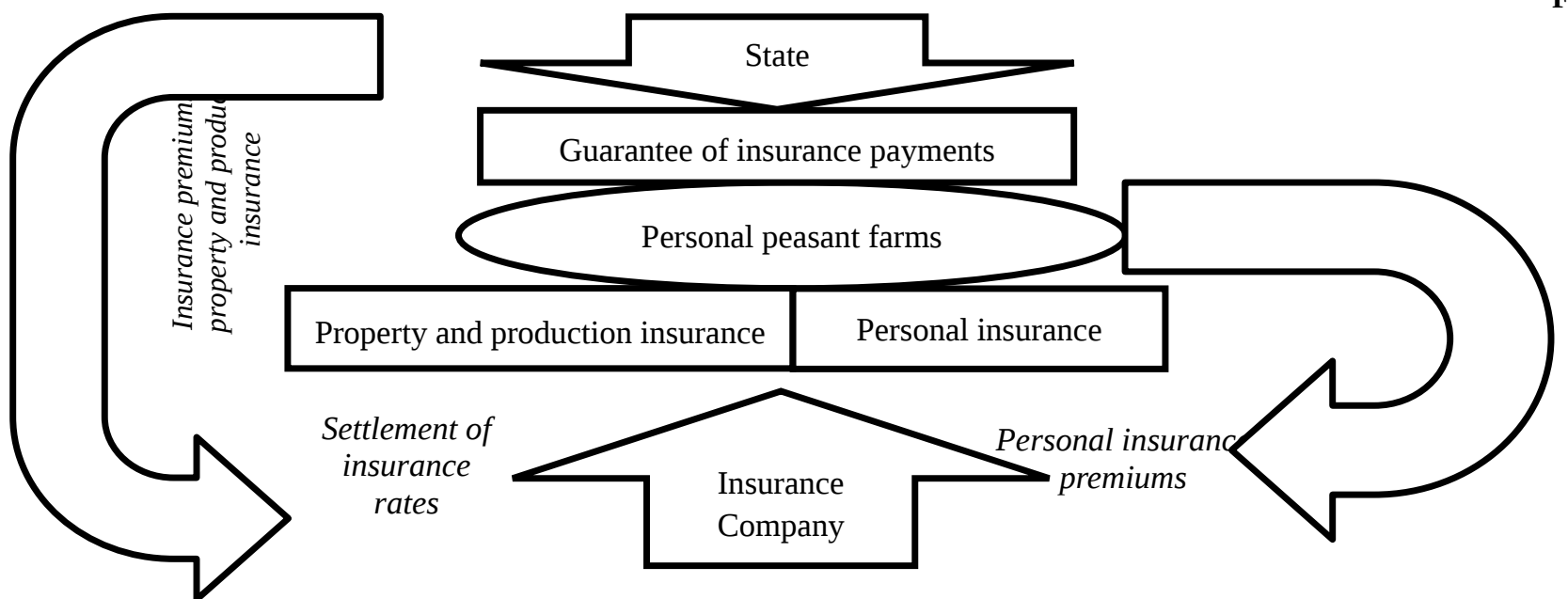

g. 7. The mechanism of microinsurance for small farmers

Implementation of state regulation in order to stimulate the development of agricultural production, taking into account social aspects through these specified mechanisms will contribute to the formation of an active social basis for further transformation:

- reducing the unemployment rate of the rural population;

- formation of a network of self-sufficient agricultural formations - territorial production clusters capable of functioning in the full cycle of agricultural production;

- improving the level of product quality;

- stimulating the financial, ecological and energy culture of agricultural production;

- balanced development of agricultural production;

- increasing the level of welfare of the rural population;

- formation of social infrastructure of rural areas.

The proposed directions of development of small agricultural producers take into account the peculiarities of the modern economy of Ukraine and are aimed at reaching a compromise between the expectations of such producers and the expectations inherent in the state. Due to the realization of the existing potential of the small and microsector of agricultural production, the real vectors of social state regulation will be realized in practice and the basis of priority of the social principle of state action will be formed.

\section{References}

1. V.V. Tomareva-Patlakhova Investments: practice and experience. 6, 38-43 (2016).

2. F. Bekele, I. Bekele (2017) https://www.researchgate.net/publication/3094173 76_Social_and_Environmental_Impacts_on_Agric ultural_Development Accessed 5 Jan 2021

3. R Stringer \& Prabhu Pingali 1(1), 1-5 (2004)

4. Y. Kustepeli, Y.Gulcan , M. Yercan, et al. Ann Reg Sci (2020) https://doi.org/10.1007/s00168019-00965-4 Accessed 15 Jan 2021
5. I.V. Zastozhnikova Scientific intelligence in state and municipal administration 1, 121-135 (2013)

6. O. Mohylnyi, O. Khodakivska Viešoji politika ir administravimas public policy and administration 17 (4), 526-538 (2018)

7. Review of agri-food trade policy in the post-Soviet countries 2017-2018. FAO. Rome. 2020.

http://www.fao.org/documents/card/en/c/ca7674ru Accessed 22 Dec 2020

8. Statistics Service of Ukraine. http://www.ukrstat.gov.ua/operativ/operativ2006/s g/sg_rik/sg_u/rosl_1991-2019_u.html Accessed 10 Jan 2021

9. State Statistics Service of Ukraine. Consumption of food in households. http://www.ukrstat.gov.ua/ Accessed 12 Jan 2021

10. Statistics Service of Ukraine. http://www.ukrstat.gov.ua/operativ/menu/menu u/ rp.ht Accessed 11 Jan 2021

11. State Statistics Service of Ukraine. The volume of output (goods, services) of enterprises by type of economic activity. http://www.ukrstat.gov.ua/ Accessed 14 Jan 2021

12. Agravery May 16 (2019). https://agravery.com/uk/ posts/show/kilkist-fermerskih-gospodarstv-zroslado-46-tisac Accessed 4 Jan 2021 